\title{
The Influence of the Major Histocompatibility Complex (H-2) on Experimental Diabetes in Mice
}

\author{
H. Kromann ${ }^{1}$, Å. Lernmark ${ }^{2}$, B. F. Vestergaard ${ }^{3}$, J. Egeberg ${ }^{3}$, and J. Nerup ${ }^{1}$ \\ ${ }^{1}$ Steno Memorial Hospital, Gentofte, Copenhagen, Denmark; 2Department of Histology, University of Umeå, Umeå, Sweden; \\ ${ }^{3}$ Departments of Medical Microbiology and Anatomy (B), University of Copenhagen, Copenhagen, Denmark
}

\begin{abstract}
Summary. Mice with different histocompatibility loci on an identical background genome (congenic resistant lines of mice) were used to study the possible influence of the histocompatibility complex on experimental diabetes. The major histocompatibility complex (H-2) was not found to influence the diabetogenic effect of encephalomyocarditis (EMC) virus. In contrast the glucose intolerance following heterologous and homologous immunization with pancreatic antigens appeared $\mathrm{H}-2$ influenced. Antibodies against cell surface components on viable B-cells were present in serum from mice with glucose intolerance induced by homologous immunization. The results suggest that the susceptibility to experimental autoimmune diabetes in mice is influenced by the $\mathrm{H}-2$ complex.
\end{abstract}

Key words: Experimental diabetes mellitus, glucose intolerance, virus, autoimmunity, immune response genes, islet-cell-surface antibody, major histocompatibility locus.

Mouse histocompatibility-2 complex ( $\mathrm{H}-2)$ linked genes control specific immune response to various extrinsic antigens [1]. The major histocompatibility complex also influences the susceptibility to certain experimental autoimmune diseases in animals e.g. thyroiditis [2], encephalomyelitis [3], myasthenia gravis [4] and possibly haemolytic anaemia [5]. We undertook a study to elucidate whether experimentally induced diabetes in mice is $\mathrm{H}-2$ dependent. Two models of experimental diabetes were used: 1 . virus induced diabetes by the encephalomyocarditis (EMC) virus [6] and the coxsackie B4 virus [7], and 2. diabetes induced by immunization with pancreatic antigens rich in endocrine tissue $[8,9]$. The experimentally diabetic mice were tested for antipancreatic autoantibodies by immunofluorescence using viable islet cells as antigen.

\section{Material and Methods}

\section{Experimental Animals (Table 1)}

All animals were 7-9 weeks old male mice (Jackson Laboratories, Bar Harbor, Maine, USA). Five different inbred strains were tested, namely C57 BL/10 Sn $(\mathrm{n}=90), \mathrm{B} 10 . \mathrm{D} 2 / \mathrm{n}$ SN $(\mathrm{n}=90)$, B10. A/Sg Sn $(n=90)$, B10. BR/Sg Sn $(n=90)$ and DBA/2 J $(n=40)$. The animals were individually marked and caged in groups of five with free access to water and standard mouse chow (Rostock mixture, Korn og Foderstof Kompagniet, Viby, Denmark) throughout the study. No animals received insulin injections. To evaluate the possible influence of the histocompatibility locus in the models, congenic resistant lines were included in the study. These lines are genetically identical except for a chromosomal segment including the histocompatibility locus [10]. That segment of a chromosome may originate from different

Table 1. The 5 strains of animals used in the study are shown to the left with the total number in parenthesis. The congenic resistant lines are genetically identical strains (C $57 \mathrm{BL} / 10 \mathrm{Sn}$ ) except for a segment of a chromosome including the histocompatibility locus originating from different donor strains

\begin{tabular}{lll}
\hline Inbred partner & $\begin{array}{l}\text { Donor } \\
\text { strain }\end{array}$ & $\begin{array}{l}\mathrm{H}-2 \\
\text { haplo- } \\
\text { type }\end{array}$ \\
\hline
\end{tabular}

Congenic resistant

lines:

B10.D2/n Sn $(n=90) \quad$ C $57 \mathrm{BL} / 10 \mathrm{Sn} \quad \mathrm{DBA} / 2 \mathrm{~J} \quad \mathrm{~d}$

B10.A/Sg Sn $(n=90) \quad$ C $57 \mathrm{BL} / 10 \mathrm{Sn} \quad \mathrm{A} / \mathrm{Wy} \mathrm{Sn} \quad$ a

B10.BR/Sg Sn $(n=90) \quad$ C $57 \mathrm{BL} / 10 \mathrm{Sn} \quad$ C $57 \mathrm{BR} / \mathrm{cd} \quad \mathrm{k}$

Inbred strains:

C $57 \mathrm{BL} / 10 \mathrm{Sn}(\mathrm{n}=90)$

$\mathrm{DBA} / 2 \mathrm{~J}(\mathrm{n}=40)$ b 
Table 2. Diabetogenic procedures

\begin{tabular}{|c|c|}
\hline $\begin{array}{l}\text { Experimental } \\
\text { groups }\end{array}$ & \\
\hline A & $50 \%(\mathrm{v} / \mathrm{v})$ emulsion of distilled water in complete \\
\hline$(\mathrm{n}=10)$ & Freund's adjuvant (CFA), $25 \mu \mathrm{l}$ intracutaneously \\
\hline $\begin{array}{l}B \\
(n=10)\end{array}$ & $\begin{array}{l}50 \%(\mathrm{v} / \mathrm{v}) \text { suspension of fetal calf pancreas anti- } \\
\text { gen corresponding with } 19 \mu \mathrm{g} \text { protein in CFA, } \\
25 \mu \mathrm{l} \text { intracutaneously }\end{array}$ \\
\hline $\begin{array}{l}\mathrm{C} \\
(\mathrm{n}=10)\end{array}$ & $\begin{array}{l}50 \%(\mathrm{v} / \mathrm{v}) \text { suspension of sonicated }(8 \mathrm{~s}) \text { isolated } \\
\mathrm{ob} / \mathrm{ob} \text { mouse islets corresponding with } 100 \mu \mathrm{g} \text { dry } \\
\text { weight in CFA, } 25 \mu \mathrm{l} \text { intracutaneously }\end{array}$ \\
\hline $\begin{array}{l}D \\
(n=10)\end{array}$ & $\begin{array}{l}\text { Eagle's minimum essential medium supplemented } \\
\text { with } 10 \%(\mathrm{v} / \mathrm{v}) \text { fetal calf serum, } 100 \mu \mathrm{l} \text { sub- } \\
\text { cutaneously }\end{array}$ \\
\hline $\begin{array}{l}E \\
(n=10)\end{array}$ & $\begin{array}{l}\text { Coxsackie B } 4 \text { virus } 10^{4} \mathrm{TCID}_{100}, 100 \mu \mathrm{l} \text { sub- } \\
\text { cutaneously in medium as D }\end{array}$ \\
\hline & Encephalomyocarditis (EMC) virus $10^{3}-10^{6}$ \\
\hline $\begin{array}{l}(\mathrm{n}=40[20 \\
\text { for the DBA } \\
2 \mathrm{~J} \text { strain]) }\end{array}$ & $\mathrm{TCID}_{100}, 100 \mu \mathrm{l}$ subcutaneously in medium as $\mathrm{D}$ \\
\hline
\end{tabular}

The experimental groups A-C represent the immunized groups of animals. The injections were placed intracutaneously in the foot pads of both hind legs in a total volume of $25 \mu \mathrm{l}$. The immunized animals received an aditional adjuvant as a $50 \mu \mathrm{l}$ subcutaneous inguinal injection of pertussis vaccine. The animals were reimmunized after the same protocol once after three weeks

The experimental groups D-F represent the virus infected groups and their control group. The inoculations were placed subcutaneously in a total volume of $100 \mu \mathrm{I}$

$\mathrm{TCID}_{100}$ : 100 per cent tissue culture infective dose

n: number of animals

donor strains and can be "built into" the inbred partner's genome by different mating systems [11]. The C $57 \mathrm{BL} / 10$ strain and three of its congenic resistant lines were used in this study, which allowed us to compare strains with the same background genome, but with four different histocompatibility haplotypes. The fifth inbred strain DBA $/ 2 \mathrm{~J}$ (only included in the virus part of the study) has the same $\mathrm{H}-2$ haplotype as one of the congenic lines, and it was therefore possible to compare strains with the same $\mathrm{H}-2$ haplotype, but with two different background genomes.

All strains of mice were established lines in the Jackson Laboratories colony. The congenicity of the lines was not tested by ourselves.

\section{Diabetogenic Procedures}

Six groups of mice were used (Table 2). The first three groups were a control group and two groups injected with pancreas extracts. The last two groups were given viruses, with the remaining group as a control.

The antigens used in groups $\mathrm{A}$ through $\mathrm{C}$ were suspended in distilled water and emulsified in complete Freund's adjuvant (CFA) (Difco Laboratories, Michigan, USA, control no. 598880) immediately before administration. The fetal calf pancreas (group B) was prepared as described previously [12] from a single calf fetus of 18-20 weeks of gestation. Samples from the same batch of antigen were used throughout the study. The non-inbred Umea strain of ob/ob mice [13] was used as the donor of mouse islets (group C). Pancreatic glands from animals fasted overnight were treated with collagenase type IV (Worthington Biochemical Corporation, Freehold, New Jersey, USA, lot no. $44 \mathrm{~K} \mathrm{151}$ ), and the islets were collected under a stereo microscope [13]. The antigens were stored at $-20^{\circ} \mathrm{C}$ until use, at which time they were emulsified in complete Freund's adjuvant, immediately before administration. The immunization procedures (groups $\mathrm{A}-\mathrm{C}$ ) were repeated three weeks after the first immunization. Simultaneously with antigen injections the animals were given pertussis vaccine (Statens Seruminstitut, Copenhagen, Denmark) corresponding to $8 \times 10^{8}$ heat-killed corpuscles.

Two viruses were tested. The coxsackie B4 virus (group E) was kindly donated by Dr. D. R. Gamble, Epsom, England, and propagated twice in VERO cells. The M strain of encephalomyocarditis virus (group F) was kindly donated by Dr. J. E. Craighead, University of Vermont, Vermont, USA [14]. This virus was propagated twice in L-cells. The virus control group (group D) received injections of the medium in which the virus was otherwise propagated. The virus preparations were stored at $-20^{\circ} \mathrm{C}$ until use.

\section{Glucose Tolerance Tests}

Pilot studies in healthy animals receiving an intraperitoneal load of $1 \mathrm{~g}$ glucose and $0.2 \mathrm{mg}$ phentolamine per $\mathrm{kg}$ body weight showed that venous blood glucose peaked after $10 \mathrm{~min}$, declining to pretest values after $60 \mathrm{~min}$. The $\alpha$-receptor blocker was added to reduce stress induced monoamine-mediated influence on glucose tolerance [15]. Blood glucose was estimated in $10 \mu \mathrm{l}$ blood samples using the glucose oxidase method (Glox Novum ${ }^{\circledR}$, Kabi, Stockholm, Sweden).

Glucose tolerance tests were performed once weekly at 10-11 a. m. in non-fasted animals, from one week after the initial immunization/infection. Blood was drawn from the retroorbital venous plexus [16] 0,10 and $60 \mathrm{~min}$ after the glucose load. To minimize day-to-day variation, glucose tolerance tests were performed simultaneously for control and test animals. The area under the blood glucose curve was calculated in each animal and the degree of glucose intolerance (glucose intolerance index) was expressed as the areas of the test animals in per cent of the areas of the controls.

\section{Islet Cell Surface Antibody (ICSA)}

The occurrence of antibodies reacting with islet-cell-surface antigens was tested by an indirect immunofluorescence test on living cells [17]. Suspensions of viable islet cells were prepared from islets of ob/ob mice consisting mainly of insulin producing B-cells [13], and incubated with mouse serum from groups A, C, D and F obtained 6 weeks after the initial immunization/infection. The sera were pooled from each group of animals and fractionated with $12 \mathrm{~g} / 100 \mathrm{ml}$ polyethyleneglycol.

The precipitate, enriched in immunoglobulins, was collected by centrifugation, freeze-dried and reconstituted to the original serum volume in tissue culture medium 199 [18] containing $5 \mathrm{mmol} / 1 \mathrm{D}$-glucose, $1 \mathrm{~g} / 100 \mathrm{ml}$ bovine serum albumin and $20 \mathrm{mmol} / 1$ N-hydroxyethylpiperazine- $\mathrm{N}^{\prime}$-2-ethane-sulfonic acid and the $\mathrm{pH}$ adjusted to 7.4 (TCM). In each experiment, roughly 200 islets, rich in B-cells, were isolated by collagenase from the pancreas of non-inbred ob/ob mice of the Umea colony. Suspensions of cells were prepared and washed in TCM as described [13]. Approximately $10^{4}-10^{5}$ cells were incubated in $100 \mu 175 \%(\mathrm{v} / \mathrm{v})$ fractionated serum for $60 \mathrm{~min}$ at $20^{\circ} \mathrm{C}$ during continuous shaking. The cells were then washed by the addition of $10 \mathrm{ml} \mathrm{TCM}$ and centrifugation for $5 \mathrm{~min}$ at $50 \times \mathrm{g}$. The cell-pellet was resuspended in $100 \mu \mathrm{l}$ fluorescein isothiocyanate (FITC) conjugated antimouse IgG (rabbit) (Miles Laboratories, Elkhart, Ind., USA, lot no. DS 302) diluted 1:10 in TCM. Following incubation for $30 \mathrm{~min}$, the 
cells were washed twice as above and finally resuspended and mounted in TCM. The cells were examined in a phase-contrast microscope equipped with a Zeiss IV FI epi-fluorescence condenser. The values denote percent intact (judged by phase-contrast microscopy) cells showing immunofluorescence among roughly 100 free cells, evaluated blind in $1-4$ separate experiments.

\section{Results}

\section{Immunization with Pancreatic Antigens}

No mortality was observed following the immunization procedures. Mean blood glucose values for the four $\mathrm{H}-2$ different strains of mice one and 6 weeks after the immunization as well as mean values of the glucose intolerance indices one, 2, 3, 4, 5 and 6 weeks after the immunization are given in Table 3 . The statistical analysis was performed on the glucose intolerance indices data.

Heterologous immunization with fetal calf pancreas produced slight glucose intolerance in the $\mathrm{H}-2^{\mathrm{a}}$ strain one week after the initial immunization and after reimmunization. The $\mathrm{H}-2^{\mathrm{b}}$ and $\mathrm{H}-2^{\mathrm{d}}$ strains achieved statistically significant glucose intolerance 2 weeks after the first immunization. Reimmunization was not effective in these two strains, nor in the $\mathrm{H}-2^{\mathrm{k}}$ strain, which was a non responder strain in respect to heterologous immunization.

Homologous immunization with isolated mouse islets appeared more effective in producing glucose intolerance. The $\mathrm{H}-2^{\mathrm{b}}$ background strain reached highly significant glucose intolerance 2 weeks after the first immunization. The congenic resistant lines demonstrated glucose intolerance throughout the study period, the most pronounced intolerance appearing one to 2 weeks after the initial immunization. The $\mathrm{H}-2^{\mathrm{d}}$ strain was the highest responding strain. As for the heterologous immunization the $\mathrm{H}-2^{\mathrm{a}}$ strain showed the highest response with respect to reimmunization.

\section{Infection with Diabetogenic Viruses (Table 3)}

No mortality was observed following infection with coxsackie B4 virus. EMC virus infection resulted in a marked mortality which for the four strains at C57 $\mathrm{BL} / 10$ background six weeks after the virus inoculation was: $\mathrm{H}-2^{\mathrm{b}}$ : 40 per cent; $\mathrm{H}-2^{\mathrm{a}}$ : 90 per cent; $\mathrm{H}-2^{\mathrm{d}}$ : 47 per cent; $\mathrm{H}-2^{\mathrm{k}}$ : 8 per cent respectively. The DBA/ $2 \mathrm{~J}$ strain had a mortality of 5 per cent.

The animals of the strains with high mortality after EMC virus infection were in very bad condition and presented with low blood glucose values. The $\mathrm{DBA} / 2 \mathrm{~J}$ strain showed a high degree of glucose in-

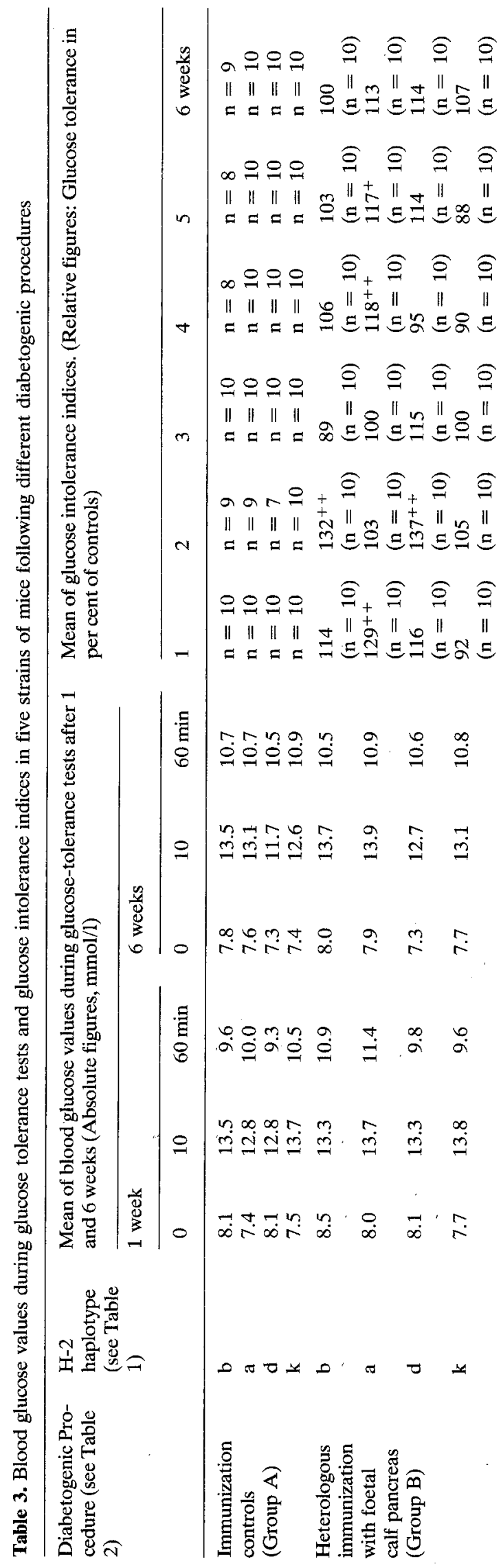




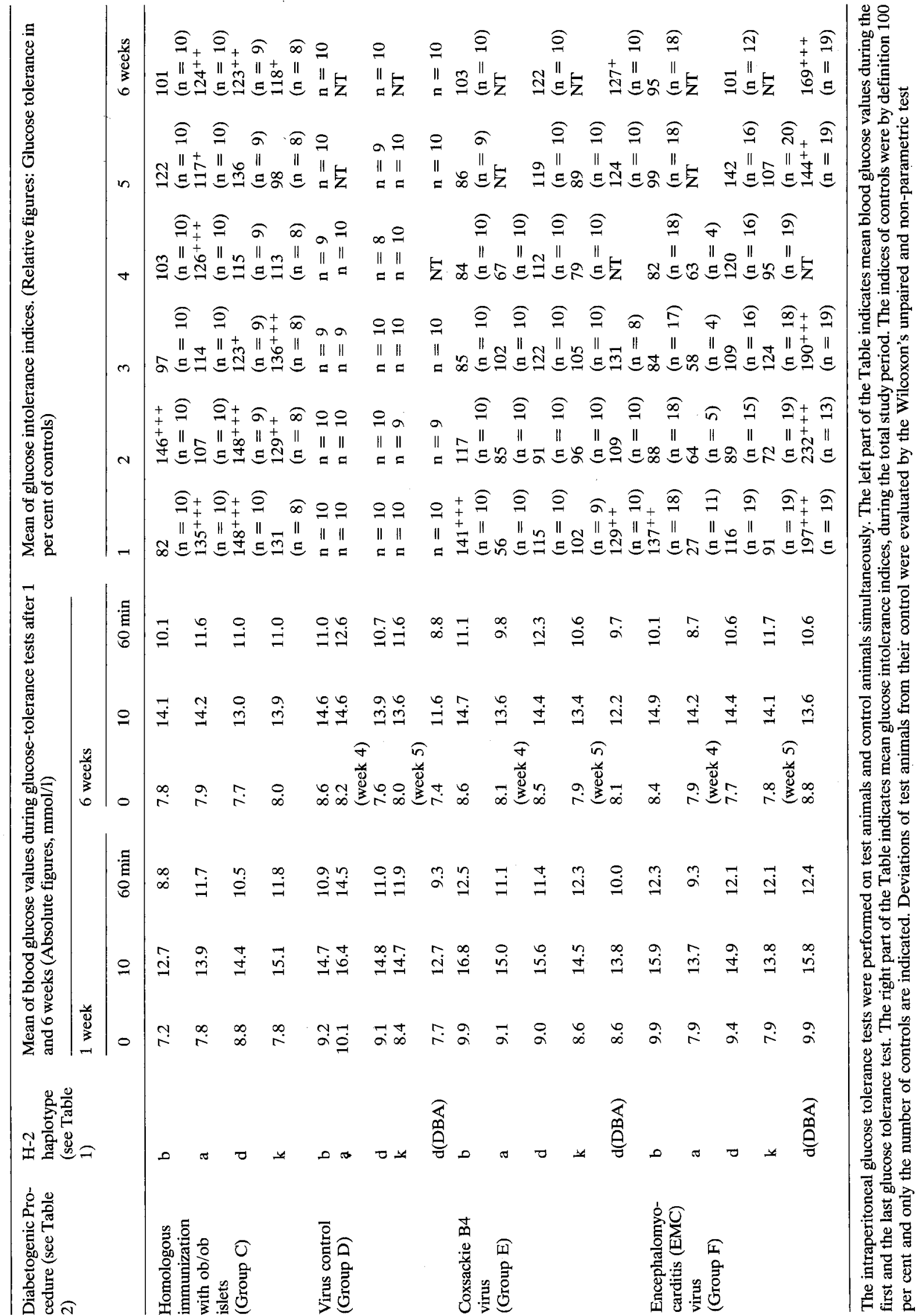



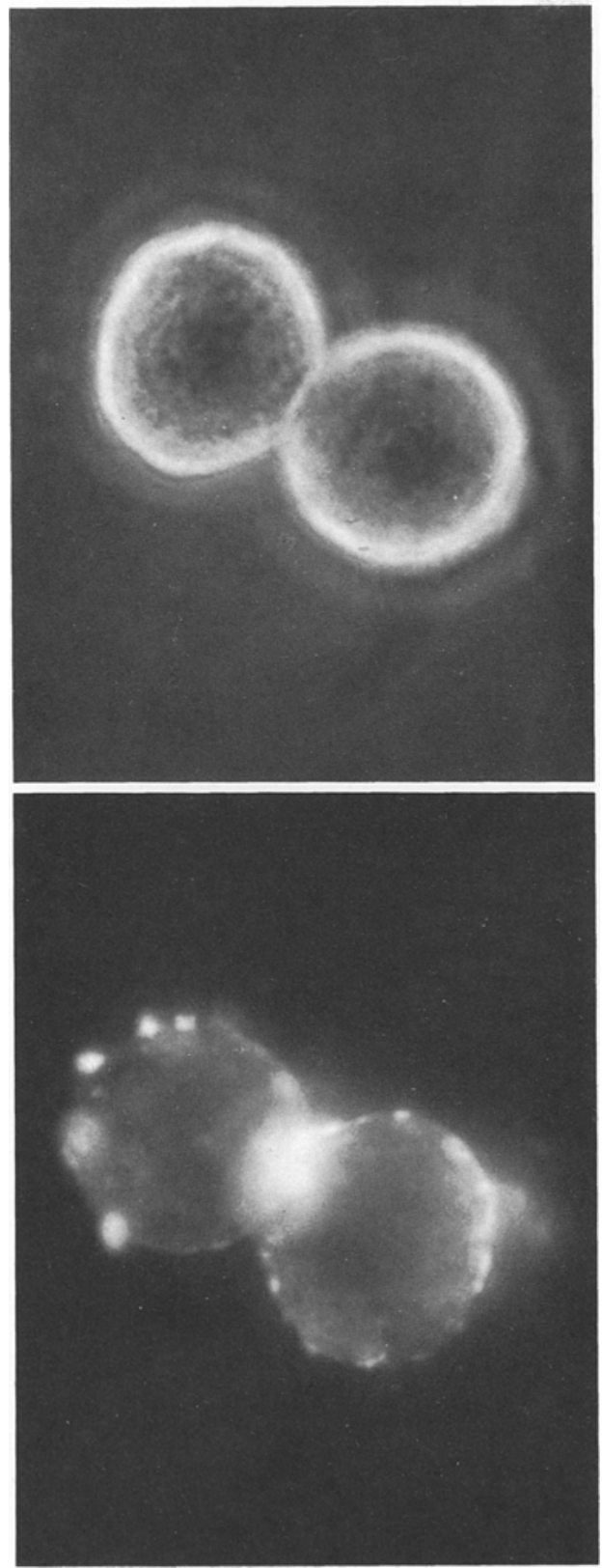

Fig. 1. Immunofluorescence staining of intact ob/ob B-cells with FITC-conjugated rabbit-anti-mouse globulin. Before being exposed to fluorescent antibodies cells were incubated with polyethylene glycol fractionated pooled serum. A phase contrast micrograph is shown on the top ( $x 2100)$. The appearance of ICSA in the fluorescence microscope is shown at the bottom. The cells shown had been incubated with $\mathrm{H}-2^{\mathrm{k}}$ serum from ob/ob mouse islet immunized animals

tolerance after EMC virus infection, maximal 2 weeks after the virus inoculation. Coxsackie B4 virus infection resulted in a less pronounced glucose intolerance in this strain. The four strains at C $57 \mathrm{BL} /$ 10 background did not respond to coxsackie B4 virus infection, the background strain itself being an
Table 4. Immunofluorescence on isolated islet cells

\begin{tabular}{lllll}
\hline H-2 haplotype & \multicolumn{4}{l}{$\begin{array}{l}\text { Per cent fluorescent cells in different } \\
\text { diabetogenic procedures }\end{array}$} \\
\cline { 2 - 5 } & Group A & Group C & Group D & Group F \\
\hline b & 13 & 36 & 16 & 38 \\
a & 18 & 41 & 18 & 11 \\
d & 19 & 44 & 4 & 11 \\
k & 46 & 58 & 45 & 40 \\
\hline
\end{tabular}

Percentage of free and intact islet cells positive for fluorescence when 100 islet cells were read blindly in 1-4 separate experiments (mean). The sera were obtained from the C $57 \mathrm{BL} / 10 \mathrm{Sn}$ strain and three of its congenic resistant lines six weeks after the diabetogenic procedures were initiated: Group A: immunization control; Group B: ob/ob islet immunization; Group D: virus-control; Group F: EMC virus infection

exception one week after the infection. The same pattern was seen after EMC virus infection.

\section{Islet Cell Surface Antibody (ICSA)}

By the indirect immunofluorescence technique a ring-shaped fluorescence could be demonstrated on free viable islet cells (Fig. 1). The relative number of fluorescent cells is given in Table 4. The percentage of positive cells when control sera were tested was between 10 and 20 , with the exception of $\mathrm{H}-2^{\mathrm{k}}$ sera which demonstrated percentages of $45-46$.

Homologous immunization resulted in an increase in ICSA formation in all four strains. EMC virus infection did not induce ICSA formation, with the possible exception of the background strain.

\section{Discussion}

In 1974 McDevitt and Bodmer [19] suggested that: "There is every reason to believe that HL-A-linked specific immuneresponse genes will be shown to be important genetic factors predisposing to resistance or susceptibility to a variety of neoplastic, autoimmune and infectious diseases in man". Almost simultaneously an HLA influenced susceptibility on insulin dependent diabetes mellitus was reported [20, 21]. Several other observations suggest that immunological mechanisms are involved in the pathogenesis of insulin dependent diabetes mellitus: mononuclear cell infiltration in and around islets of Langerhans in newly diagnosed diabetics [22], antipancreatic cell-mediated autoimmunity in newly diagnosed diabetics [23], and islet cell antibodies in patients at the time of diagnosis of diabetes [24]. On the basis of these findings we suggested the following 
hypothesis concerning the aetiology and pathogenesis of insulin dependent diabetes mellitus in man: " 1 . The inherited susceptibility in certain individuals to develop juvenile diabetes mellitus when exposed to some environmental factors (virus? chemical agents?) is at least in part conferred by HLADw3 and Dw4-associated immune response genes (Ir-genes). 2. In susceptible individuals these Irgenes cause a defective T-cell response (T-B lymphocyte cooperation) against environmental factors, leading to B-cell destruction directly or through autoimmune mechanisms" [25].

The present study was undertaken to elucidate whether experimental diabetes in mice is also influenced by the histocompatibility locus. Lilly and coworkers discovered an $\mathrm{H}-2$ linked genetic control on the relative resistance to Gross virus-induced leukemogenesis [26]. H-2 linked control of virus susceptibility has been confirmed by a series of studies including congenic resistant lines [27]. This genetic control is thought most likely to be explained by immune response genes located within the $\mathrm{H}-2$ locus. McDevitt and Sela reported that the antibody response to certain synthetic polypeptides was genetically controlled [28], and this control was found to be H-2 linked [1]. The immune response genes seem to control the specificity of antigen recognition mainly by thymus derived lymphocytes (T-cells) [29].

Our data on EMC virus infection showed an $\mathrm{H}-2$ influenced mortality range from $8\left(\mathrm{H}-2^{\mathrm{k}}\right)$ to 90 $\left(\mathrm{H}-2^{\mathrm{a}}\right)$ per cent in congenic resistant lines. The background genome, however, also influenced the mortality, since the DBA/2 J $\left(\mathrm{H}-2^{\mathrm{d}}\right)$ strain only presented with a mortality of 5 per cent compared with 47 per cent of the B10. D2 $\left(\mathrm{H}-2^{\mathrm{d}}\right)$ strain. The diabetogenic effect of EMC virus was not $\mathrm{H}-2$ influenced. The background genome, however, greatly influenced the degree of glucose intolerance, since the $\mathrm{DBA} / 2 \mathrm{~J}$ strain was a high responder strain in contrast to the B10. D2 strain, though these two strains share the same $\mathrm{H}-2$ haplotype (d). The lack of $\mathrm{H}-2$ influence is in accordance with studies [30] in which 19 inbred strains of mice were tested after EMC virus infection. Some of the variation in susceptibility to EMC virus seems to be caused by genetic differences in the B-cell itself, since EMC virus replicated up to 50 -fold better in islet cells from $S W R / j$ mice than in islet cells from C57 BL/6J mice [31]. These two strains of mice were high and low responders, respectively, to the diabetogenic action of EMC virus in vivo. Other data, however, suggest immunological mechanisms to be involved in the diabetogenic action of EMC virus. We reported [32] that certain dosages of EMC virus evoked maximal glucose intolerance three weeks after virus inoculation, i. e. two weeks after the acute viral pancreatitis, and we suggested that cell-mediated immunity, leading to delayed islet damage, might be involved. Two reports [33], [34], describe a similar delay in diabetogenic action of EMC virus and studies [35] with $\mathrm{X}$-irradiation and chemical immunosuppression further suggest that the appearance of diabetes depends on immune reactions. Our preliminary results on ICSA formation after EMC virus infection further suggest that immunological mechanisms might be involved. The Coxsackie virus pancreatitis in mice [36] was found to be connected with diabetes [7]. In our studies the diabetogenic effect of Coxsackie virus was not convincing.

The data presented in this paper are suggestive of H-2 influenced susceptibility of the diabetogenic effect of immunization with pancreatic antigens. Strains differing only at the $\mathrm{H}-2$ locus presented with different patterns of glucose intolerance. Homologous immunization with isolated islets was more effective than heterologous immunization. The $\mathrm{H}-2^{\mathrm{d}}$ strain was the highest responding strain and the $\mathrm{H}-2^{\mathrm{a}}$ strain the best responding strain in respect to reimmunization. The $\mathrm{H}-2^{\mathrm{b}}$ strain reached significant glucose intolerance after 2 weeks, which confirms our earlier studies with homologous immunization [37], in which studies we also demonstrated that the antigen was different from insulin. Wright and coworkers [38] demonstrated that periductulitis, with areas of infiltration by small lymphocytes, when guinea pigs were immunized with islets of Langerhans, was not correlated with the levels of insulin-binding antibodies in plasma. In autoimmune murine thyroiditis [2] the $\mathrm{H}-2^{k}$ strains were high responders and the $\mathrm{H}-2^{\mathrm{d}}$ strains poor responders with regard to antibody formation and thyroid damage.

ICSA were demonstrable in the immunized animals and surprisingly so in untreated $\mathrm{H}-2^{\mathrm{k}}$ mice. These animals did not become spontaneously diabetic. The occurrence of a circulating "auto-antibody" to B-cell surface antigen(s) has not been reported before in experimental animal models of diabetes. A similar finding of an islet cell surface antibody in rabbits immunized with viable dispersed islet cells was recently reported [39], and we reported [40] that antibodies, with the same features as described in this paper, were present in serum from newly diagnosed patients with insulin-dependent diabetes. However, further studies are needed to elucidate whether ICSA interferes with B-cell function.

In analogy with the situation in spontaneous insulin-dependent diabetes mellitus in man, the present study suggests that interplay between immune 
response genes and exogenous B-cell damaging agents is essential in the production of diabetes in mice.

Thus the use of experimental animal models of insulin-dependent diabetes mellitus could well prove useful in future studies of diabetes aetiology and pathogenesis.

Acknowledgement. This work was supported by Statens Laegevidenskabelige Forskningsråd, j. no. 512-6588.

\section{References}

1. McDevitt, H. O., Chinitz, A.: Genetic control of the antibody response: Relationship between immune response and histocompatibility (H-2) type. Science 163, 1207-1208 (1969)

2. Vladutiu, A. O., Rose, N. R.: Autoimmune murine thyroiditis. Relation to histocompatibility (H-2) type. Science 174, 1137-1139 (1971)

3. Gasser, D. L., Newlin, C. M., Palm, J., Gonatas, N. K.: Genetic control of susceptibility to experimental allergic encephalomyelitis in rats. Science 181, 872-873 (1973)

4. Fuchs, S., Nevo, D., Tarrab-Hazdai, R., Yaar, I.: Strain differences in the autoimmune response of mice to acetylcholine receptors. Nature 263, 329-330 (1976)

5. Warner, N. L.: Genetic control of spontaneous and induced antierythrocyte autoantibody production in mice. Clin. Immunol. Immunopathol. 1, 353-363 (1973)

6. Craighead, J. E., McLane, M. F.: Diabetes mellitus: Induction in mice by encephalomyocarditis virus. Science 162, 913-914 (1968)

7. Coleman, T. J., Gamble, D. R., Taylor, K. W.: Diabetes in mice after coxsackie B4 virus infection. Br. Med. J. 1973 III, 25-27

8. Nerup, J., Andersen, O. O., Bendixen, G., Egeberg, J., Poulsen, J. E., Vilien, M., Westrup, M.: Anti-pancreatic, cellular hypersensitivity in diabetes mellitus. Experimental induction of anti-pancreatic, cellular hypersensitivity and associated morphological $\beta$-cell changes in the rat. Acta Allergol. (Kbh.) 28, 231-249 (1973)

9. Nerup, J., Andersen, O. O., Bendixen, G., Egeberg, J., Gunnarsson, R., Kromann, H., Poulsen, J. E.: Glucose intolerance and islet damage in mice immunized with homologous endocrine pancreas-A preliminary communication. Horm. Metab. Res. 6, 173-175 (1974)

10. Klein, J.: Biology of the mouse histocompatibility- 2 complex, p. 31. Berlin, Heidelberg, New York: Springer 1975

11. Snell, G.D.: Methods for the study of histocompatibility genes. J. Genet. 49, 87-108 (1948)

12. Nerup, J., Andersen, O.O., Bendixen, G., Egeberg, J., Poulsen, J. E.: Anti-pancreatic, cellular hypersensitivity in diabetes mellitus. Antigenic activity of fetal calf pancreas and correlation with clinical type of diabetes. Acta Allergol. (Kbh.) 28, 223-230 (1973)

13. Lernmark, $\AA$.: The preparation of, and studies on, free cell suspensions from mouse pancreatic islets. Diabetologia 10, 431-438 (1974)

14. Craighead, J. E.: Pathogenicity of the $M$ and $E$ variants of the encephalomyocarditis (EMC) virus. Am. J. Pathol. 48, 333-342 (1966)

15. Hermann, L. S., Deckert, T.: The effect of epinephrine and isoproterenol on insulin secretion and glucose utilization in isolated islets of Langerhans from mice. Acta Endocrinol. (Kbh.) 84, 105-114 (1977)

16. Stone, S. H.: Method for obtaining venous blood from the orbital sinus of the rat or mouse. Science 119, 100 (1954)

17. Möller, G.: Demonstration of mouse isoantigens at the cellular level by the fluorescent antibody technique. J. Exp. Med. 114, 415-434 (1961)

18. Salk, J. E., Youngner, J. S., Ward, E. N.: Use of color change of phenol red as the indicator in titrating poliomyelitis virus as its antibody in a tissue culture system. Am. J. Hyg. 60, 214-230 (1954)

19. McDevitt, H. O., Bodmer, W. F.: HL-A, immune-response genes, and disease. Lancet 1974 I, 1269-1275

20. Singal, D. P., Blajchmann, M. A.: Histocompatibility (HL-A) antigens, lymphocytotoxic antibodies and tissue antibodies in patients with diabetes mellitus. Diabetes 22, 429-432 (1973)

21. Nerup, J., Platz, P., Andersen, O. O., Christy, M., Lyngsø, J., Poulsen, J. E., Ryder, L. P., Staub Nielsen, L., Thomsen, M., Svejgaard, A.: HL-A antigens and diabetes mellitus. Lancet 1974 II, 864-866

22. Gepts, W.: Pathologic anatomy of the pancreas in juvenile diabetes mellitus. Diabetes 14, 619-633 (1965)

23. Nerup, J., Andersen, O. O., Bendixen, G., Egeberg, J., Poulsen, J. E.: Antipancreatic cellular hypersensitivity in diabetes mellitus. Diabetes 20, 424-427 (1971)

24. Bottazzo, G. F., Florin-Christensen, A., Doniach, D.: Isletcell antibodies in diabetes mellitus with autoimmune polyendocrine deficiencies. Lancet 1974 II, 1279-1283

25. Nerup, J., Platz, P., Andersen, O. O., Christy, M., Egeberg, J., Lyngsø, J., Poulsen, J. E., Ryder, L. P., Thomsen, M., Svejgaard, A.: HLA, autoimmunity and insulin-dependent diabetes mellitus. In: The genetics of diabetes mellitus. Creutzfeldt, W., Köbberling, J., Neel, J. V., (Eds.). p. 106. Berlin, Heidelberg, New York: Springer 1976

26. Lilly, F., Boyse, E. A., Old, L. J.: Genetic basis of susceptibility to viral leukaemogenesis. Lancet 1964 II, 1207-1209

27. Klein, J.: Biology of the mouse histocompatibility-2 complex, pp. 389-411. Berlin, Heidelberg, New York: Springer 1975

28. McDevitt, H. O., Sela, M.: Genetic control of the antibody response. I. Demonstration of determinant-specific differences in response to synthetic polypeptide antigens in two strains of inbred mice. J. Exp. Med. 122, 517-531 (1965)

29. Tyan, M. L., McDevitt, H. O., Herzenberg, L. A.: Genetic control of the antibody response to a synthetic polypeptide: Transfer of response with spleen cells or lymphoid precursors. Transplant. Proc. 1, 548-550 (1969)

30. Boucher, D. W., Hayashi, K., Rosenthal, J., Notkins, A. L.: Virus-induced diabetes mellitus. III. Influence of the sex and strain of the host. J. Infect. Dis. 131, 462-466 (1975)

31. Yoon, J.-W., Notkins, L. A.: Virus-induced diabetes mellitus. VI. Genetically determined host differences in the replication of encephalomyocarditis virus in pancreatic beta cells. J. Exp. Med. 143, 1170-1185 (1976)

32. Kromann, H., Vestergaard, B. F., Nerup, J.: Glucose intolerance in mice infected with encephalomyocarditis virus. Acta Endocrinol. (Kbh.) 76, 670-677 (1974)

33. Buschard, K., Rygaard, J., Lund, E.: The inability of a diabetogenic virus to induce diabetes mellitus in athymic (nude) mice. Acta Pathol. Microbiol. Scand. [C] 84, 299-303 (1976)

34. Jansen, F. K., Müntefering, H., Schmidt, W. A. K., Biener, J.: Suggestion that immune reactions are needed for diabetes developing after EMC virus infection in the mouse. Diabetologia 13, 404-405 (1977)

35. Jansen, F. K., Müntefering, H., Schmidt, W. A. K.: Virus 
induced diabetes and the immune system. Diabetologia 13, 545-549 (1977)

36. Pappenheimer, A. M., Kunz, L. J., Richardson, S.: Passage of coxsackie virus (Connecticut-5 strain) in adult mice with production of pancreatic disease. J. Exp. Med. 94, 45-65 (1951)

37. Egeberg, J., Nerup, J., Andersen, O. O., Bendixen, G., Kromann, H., Gunnarsson, R., Hellerström, C., Poulsen, J. E.: Morphology of experimental, organ-specific insulitis of the mouse pancreas. Acta Endocrinol. (Kbh.) 83, 133-150 (1976)

38. Wright. P. H., Gingerich, R. L., King, S., Lacy, P. E.: Pancreatic lesions induced in rabbits and guinea-pigs with pancreatic antigens. Clin. Exp. Immunol. 25, 328-337 (1976)

39. Lernmark, $\AA$., Patzelt, C., Diakoumis, K., Carrol, R., Steiner, D. F.: Production of islet cell surface antibody in rabbits im- munized with viable, dispersed islet cells. Diabetes 27, 458 (1978)

40. Lernmark, Å., Sehlin, J., Täljedal, I.-B., Kromann, H., Nerup, J.: Possible toxic effects of normal and diabetic patient serum on pancreatic $\beta$-cells. Diabetologia 14, 25-31 (1978)

Received: April 16, 1978,

and in revised form: August 31, 1978

H. Kromann

Steno Memorial Hospital

DK-2820 Gentofte

Denmark 